\title{
Influence of pasteurization of milk and addition of starter cultures on protein breakdown in ovine cheeses manufactured with extracts from flowers of Cynara cardunculus
}

\author{
M. J. Sousa \& F. X. Malcata* \\ Escola Superior de Biotecnologia, Universidade Católica Portuguesa, Rua Dr. António Bernardino de Almeida, 4200 Porto, Portugal
}

\begin{abstract}
Ovine cheeses were manufactured from raw milk $(R)$, pasteurized milk without starter addition $(P)$, and pasteurized milk with starter addition $(P S)$, using in all cases extracts of Cynara cardunculus as rennet and mimicking as far as possible the traditional manufacture process. The microbial counts were higher in $R$ cheeses than in $P$ chceses, and the lowest microbial counts were found for $P S$ cheeses. Such physicochemical characteristics as moisture, fat, protein, $\mathrm{NaCl}$ content, and $\mathrm{pH}$ of the three types of cheeses were similar to one another at each sampling time. In particular, pasteurization had no significant effect on protein breakdown as evaluated by either the water-soluble nitrogen, the trichloroaceticacid (TCA)-soluble nitrogen, or the phosphotungstic acid (PTA)-soluble nitrogen fractions. However, the TCA-soluble and the PTA-soluble fractions for the $P S$ cheeses ripened for more than 28 days were higher than those for the $R$ or $P$ cheeses at similar ripening times. The cheeses and their water-soluble extracts could not be distinguished by urea-polyacrylamide gel electrophoresis for up to 7 days, but clear differences were apparent at 68 days of ripening for the $P S$ cheeses with respect to the $R$ and $P$ cheeses. Copyright (C) 1996 Elsevier Science Ltd
\end{abstract}

\section{INTRODUCTION}

Pasteurization of milk prior to manufacture of cheese has been widely employed with the aim of reducing the numbers of viable microorganisms (which are often illdefined wild species) and thus avoiding public health hazards. Pasteurization is, however, more than a pathogen destruction step because it eliminates all microorganisms but those that can survive at $72^{\circ} \mathrm{C}$ for $15 \mathrm{~s}$ or at $63^{\circ} \mathrm{C}$ for $30 \mathrm{~min}$ (Thomas et al., 1950). In addition, air-borne contaminants may gain access to milk after pasteurization. Therefore, the pasteurized milk in the cheese vat will have its own population of thermoduric and other contaminant microorganisms prior to deliberate addition of starter. Normally, the quantity of starter added at the beginning of cheesemaking is such that the starter organisms are by far the dominant microbial population at levels of $10^{6}-10^{7} / \mathrm{ml}^{1}$ of milk. During the manufacturing steps further opportunity exists for contaminants to enter the system, either

*To whom correspondence should be addressed. via ingredients added during manufacture or from the cheesemaking equipment itself.

For a long time the perception that cheese manufactured from pasteurized milk does not develop such a mature flavour as cheese manufactured from raw milk has built up among consumers. In fact, cheese manufactured from raw milk tends to develop a stronger flavour and generally ripens more quickly (Sherwood, 1936; Scarpelino \& Kosikowski, 1962; Price \& Call, 1969). The quantities of water-soluble nitrogen (WSN) and free amino acids (FAA) increase during ageing of cheese manufactured from pasteurized and raw milks (Lane \& Hammer, 1935; Bullock \& Irvine, 1956), but pasteurization of milk prior to cheesemaking decreases the WSN and FAA found in cheese for a given ripening time as compared with cheese manufactured from raw milk for the same ripening time (Kosikowski, 1951; Bullock \& Irvine, 1956; O'Keeffe et al., 1976). The use of aseptic cheese vats and defined strains of starter bacteria has demonstrated that the starter alone could be responsible for the development of distinct Cheddar cheese flavour (Visser, 1977; Visser \& de Groot-Mostert, 
1977), although such cheeses lacked the full flavour of a mature typical Cheddar (Perry \& McGillivray, 1964; Reiter et al., 1969). The quantitative and qualitative differences of proteolysis in cheeses manufactured from pasteurized instead of raw milk were attributed to deactivation of native milk enzymes (or destruction of microorganisms) and alteration of the milk component structure via thermally induced interactions of proteins that constrain the proteolytic action of rennet in the cheese curd (Sherwood, 1936; Melạchouris \& Tuckey, 1966; O'Keefe et al., 1976). Lau et al. (1991) compared cheeses manufactured from raw and pasteurized milk using sophisticated analytical techniques and concluded that both the extent and characteristics of proteolysis were altered by pasteurization. It was postulated that heat-induced whey protein-casein interactions that reduced the accessibility of the caseins to enzyme action could account for this fact. However, the possibility that the observed differences were also a consequence of some degree of inactivation of milk proteinases or non-starter lactic acid bacteria (NSLAB) was not fully precluded (Lau et al., 1991; McSweeney et al., 1993a).

As a result of the above findings, attention has focused on the possible contribution of non-starter lactic acid bacteria (NSLAB) to the development of cheese flavour. NSLAB are commonly found in ripened cheeses in high numbers and derive either from contaminated milk or from adventitious contaminants contributed by the factory environment (Naylor \& Sharpe, 1958; Marth, 1963; Fryer \& Sharpe, 1966; Law et al., 1976; Turner, 1988; Martley \& Crow, 1993; McSweeney et al., 1993a). From observations encompassing a wide range of experimental cheeses manufactured with defined-strain lactic starters coupled with the addition of a number of other cultures (leuconostocs, lactobacilli and pediococci), Martley \& Crow (1993) suggested that several interactions are possible between such added cultures and adventitious NSLAB during cheese ripening; hence pasteurization may play a key role in avoiding such interactions via reduction of entry of undesirable adventitious NSLAB into the commercial cheesemaking process. McSweeney et al. (1993a) have compared the ripening characteristics of Cheddar cheese manufactured from raw, pasteurized and microfiltered milk in order to assess the significance of NSLAB in cheese ripening and concluded that the indigenous microflora of milk markedly affect the quality of the final Cheddar cheese obtained.

The objectives of this study were to determine the influence of pasteurization of milk and addition of starter cultures prior to cheesemaking on protein breakdown (measured by the water-soluble, the trichloroacetic acid-soluble, and the phosphotungstic acid-soluble nitrogen fractions and by the extent of degradation of $\alpha_{\mathrm{s}}-$ and $\beta$-caseins) in ovine cheeses manufactured with a plant rennet consisting of extracts of flowers of Cynara cardunculus.

\section{MATERIALS AND METHODS}

\section{Cheesemaking}

Raw ovine milk from the Serra da Estrela region was collected from a selected farm on the very morning of cheesemaking and transported to the D.R.A.E.D.M. premises in Paços de Ferreira. Prior to cheesemaking, the raw milk was divided into three portions: two were batch-pasteurized at $72^{\circ} \mathrm{C}$ for $15 \mathrm{~s}$ and the other received no heat treatment. One of the pasteurized batches was further treated with the commercial starter Flora danica(III) DRI/vac (Chr. Hansen's Lab, Denmark) at the recommended level. Cheeses were manufactured on the same day from raw milk (denoted hereafter as $R$ ), pasteurized milk (denoted hereafter as $P$ ), and pasteurized milk added with the starter culture (denoted herafter as $P S$ ), using in all cases extracts of Cynara cardunculus as rennet and following an adaptation of the traditional technology. The milk was heated to $28^{\circ} \mathrm{C}$, salted (300 g/100 1), renneted (16 g/100 1), and left to coagulate for $60 \mathrm{~min}$. The curd was cut, stirred for $30 \mathrm{~min}$, allowed to set and permit a quick draining, placed into cylindrical molds, and lightly pressed by hand. The cheeses were salted with dry salt on both surfaces and $24 \mathrm{~h}$ later were placed in a maturation chamber at $6^{\circ} \mathrm{C}$ and $92 \%$ relative humidity. After 14-20 days the cheeses were washed with warm salted water. The cheeses were turned upside down daily for 68 days. Fourteen independent cheeses of each type $(R, P$, and $P S)$ were manufactured according to this protocol.

\section{Analyses}

One cheese of each type ( $R, P$ and $P S)$ taken at random at 0,28 and 68 days of ripening was sampled for microbiological analyses. Cheese samples $(10 \mathrm{~g})$ were homogenised with $90 \mathrm{ml}$ of a sterile solution of $2 \%(\mathrm{w} / \mathrm{v})$ sodium citrate (Merck, Darmstadt, Germany) for $3 \mathrm{~min}$ in a Stomacher Lab-Blender 400 (Seward Medical, London, UK). Sequential decimal dilutions were made with sterile $0.1 \%$ peptone water (Sigma Chemical, St. Louis MO, USA) and plated in duplicate on a range of media: total viable counts were determined from Plate Count Agar (PCA) (Lab M, Bury, UK) incubated at $30^{\circ} \mathrm{C}$ for 3 days under aerobic conditions; lactic acid bacteria (LAB) were grown anaerobically using a GasPak anaerobic system (BBL, Cockeysville MD, USA) on M17 agar (M17A) (Merck) and on Rogosa agar (RA) (Merck) at $30^{\circ} \mathrm{C}$ for 3 and 5 days using cycloheximide (Sigma) as additive at $100 \mathrm{mg} / \mathrm{l}^{-1}$ to prevent growth of yeasts; yeasts and moulds were grown on potato dextrose agar (PDA) (Lab M) acidified with $10 \%$ lactic acid (Merck) at $25^{\circ} \mathrm{C}$ for 5 days, enterobacteria were determined on Violet red bile glucose agar (VRBGA) (Merck) at $37^{\circ} \mathrm{C}$ for 1 day, and pseudomonas were determined on Agar Base (AB) (Lab M) at $30^{\circ} \mathrm{C}$ for 2 days. All microbiological counts were made 
according to the surface viable count technique of Miles \& Misra (1938) except for VRBGA counts which were determined by the pour-plate technique of Busta et al. (1984). The results were expressed as $\mathrm{cfu} / \mathrm{g}_{\text {cheese }}{ }^{-1}$. All determinations were made in duplicate.

\section{Chemical analyses}

Two cheeses of each type $(R, P$, and $P S)$ taken at random at $0,7,14,28,42,56$, and 68 days of ripening were sampled for chemical analyses. The total solids content (TS) was determined by oven drying at $100^{\circ} \mathrm{C}$ as described by Kosikowski (1982). Salt ( NaCl) was assayed by the modified Volhard method using silver nitrate and potassium thiocyanate (Merck) as described by Kosikowski (1982). The $\mathrm{pH}$ was measured by directly probing the cheese with a glass electrode connected to a potentiometer Microph 2001 (Crison, Barcelona, Spain). The total nitrogen (TN) content of cheese was determined by the micro-Kjeldahl method using a Kjeltec system 1002 Distilling unit (Tecator, Höganäs, Sweden). The fat content was determined by the Van Gulik method (Anon, 1975) using 40\% sulphuric acid (PronaLab, Lisbon, Portugal): after addition of each acid portion, the butyrometer was well shaken until all protein was digested; following addition of a few drops of amylic acid (PronaLab), the butyrometers were centrifuged (Norma milk-G24, Milan, Italy) and the fat percentage was read. All determinations were made in duplicate.

\section{Biochemical analyses}

Two cheeses of each type $(R, P$, and $P S)$ taken at random at $0,7,14,28,42,56$, and 68 days of ripening were sampled for biochemical analyses. Water-soluble nitrogen (WSN) was determined by the procedure of Kuchroo \& Fox (1982). Grated cheese ( $x \mathrm{~g}$ ) was homogenized with $2 x \mathrm{ml} \mathrm{H}_{2} \mathrm{O}$ for $5 \mathrm{~min}$ using a Stomacher 400 (Colworth, London, UK), and the resulting homogenate was then held at $40^{\circ} \mathrm{C}$ for $1 \mathrm{~h}$. Following incubation, the insoluble material was separated by centrifugation at $10000 \mathrm{~g}$ for $30 \mathrm{~min}$ in a refrigerated centrifuge (Sorval RC5C, Wilmington, USA) at $4^{\circ} \mathrm{C}$ and the supernatant was filtered through glass wool. Samples of water-insoluble nitrogen (WISN) and WSN were freeze-dried for further analysis. All determinations were made in duplicate.

Trichloroacetic acid (TCA)-soluble extract was prepared by adding $y \mathrm{ml}$ of $48 \%$ TCA to $4 y \mathrm{ml}$ of WSN. The mixture was allowed to stand for $30 \mathrm{~min}$ at $20^{\circ} \mathrm{C}$ and filtered through Whatman No. 42 filter paper (Maidstone, UK). The nitrogen content was determined on an aliquot of the filtrate. Phosphotungstic acid (PTA)-soluble extract was prepared by adding $14.0 \mathrm{ml}$ of $\mathrm{H}_{2} \mathrm{SO}_{4}(3.95 \mathrm{M}$ ) (PronaLab) and $6 \mathrm{ml}$ of PTA $(33.3 \%(\mathrm{w} / \mathrm{v}))$ to $20 \mathrm{ml}$ of WSN. The mixture was allowed to stand overnight at $4^{\circ} \mathrm{C}$ and subsequently filtered through Whatman no. 542 filter paper. The nitrogen contents in aliquots of the water-soluble, the TCA-soluble, and the PTA-soluble extracts were determined by the micro-Kjeldahl procedure. The ripening extension index, WSN/TN (which is a measure of proteolytic activity), the ripening depth index, TCA/TN (which is a measure of aminopeptidase activity of the starter bacteria in cheese) (Furtado \& Partridge, 1988), and the ratio PTA/TN (free amino acid index) (Aston et al., 1983) were duly calculated from the experimental data. All determinations were made in duplicate.

Urea-polyacrylamide gel electrophoresis (PAGE) (12.5\% C, 4\% T, pH 8.9) was performed on cheese samples, as well as on water-soluble and water-insoluble extracts thereof, using a Protean II XI vertical slab-gel unit (Bio-Rad Laboratories, Watford, UK) and the stacking gel system of Andrews (1983) with modifications (Shalabi \& Fox, 1987). The gels were stained with coomassie blue G-250 (Bio-Rad, Richmond CA, USA) using the method of Blakesley \& Boezi (1977). All determinations were made in duplicate.

\section{RESULTS AND DISCUSSION}

\section{Microbiological analyses}

The numbers of total viable counts on PCA, lactococci on M17A, lactobacilli on RA, enterobacteria on VRBGA, pseudomonas on $\mathrm{AB}$, and yeasts and moulds on PDA for the raw and pasteurized milks are summarized in Table 1 .

Total viable microorganisms in the $R$ cheeses were detected at 0 days of ripening $\left(10^{6} \mathrm{cfu} / \mathrm{g}^{-1}\right)$, and showed an increase during the first day of ripening followed by a decrease toward 68 days of ripening (Table 1). Total viable microorganisms in pasteurized cheese ( $P$ and $P S)$ existed in lower counts than in raw cheese, but a similar trend throughout ripening was observed (Table 1). Enterobacteria were virtually absent from pasteurized milk (Table 1) and pasteurized cheeses (Table 1) on the first day of ripening; however, these microorganisms increased toward 28 days of ripening $\left(10^{6}, 10^{7}\right.$, and $10^{3}$ $\mathrm{cfu} / \mathrm{g}^{-1}$ in the $R, P$ and $P S$ cheeses, respectively) (Table 1). Although enterobacteria were present at high levels in the interior of the cheese during late stages of ripening, higher numbers have been reported for La Serena and Majorero cheeses (Fernández del Pozo et al., 1988a; Fontecha et al., 1990). The presence of enterobacteria during late stages of maturation suggests that these bacteria play a role in the ripening of this variety of cheese. Yeasts and moulds were also absent from raw or pasteurized milk (Table 1) and from pasteurized cheese on the first day, as well as from pasteurized cheese after 28 days of ripening, but increased toward 68 days to $10^{4}, 10^{2}$, and $10^{3} \mathrm{cfu} / \mathrm{g}^{-1}$ in the $R, P$ and $P S$ cheeses, respectively. Yeasts and moulds play an important role in breakdown of proteins and triglycerides. However, 
Table 1. Numbers of total viable counts on PCA, lactococci on M17A, lactobacilli on RA, enterobacteria on VRBGA, pseudomonas on AB and yeasts and moulds on PDA for ovine cheeses manufactured from (a) raw milk, (b) pasteurized milk without starter addition, and (c) pasteurized milk with starter addition, using extracts of Cynara cardunculus as rennet

\begin{tabular}{lccccc}
\hline $\begin{array}{l}\text { Viable microflora } \\
\text { (cfu/gcheese }{ }^{-1} \text { ) }\end{array}$ & & Milk & 0 days & $\begin{array}{c}\text { Cheese } \\
28 \text { days }\end{array}$ & 68 days \\
\hline VRBGA & a & $4.6 \times 10^{3}$ & $6.2 \times 10^{5}$ & $1.7 \times 10^{6}$ & $1.7 \times 10^{7}$ \\
& b & $<10^{2}$ & $<10^{2}$ & $9.9 \times 10^{7}$ & $1.4 \times 10^{7}$ \\
PCA & $\mathrm{c}$ & $<10^{2}$ & $<10^{2}$ & $2.9 \times 10^{3}$ & $6.8 \times 10^{4}$ \\
& $\mathrm{a}$ & $5.5 \times 10^{3}$ & $4.7 \times 10^{6}$ & $2.5 \times 10^{9}$ & $3.4 \times 10^{8}$ \\
M17 & $\mathrm{b}$ & $2.1 \times 10^{4}$ & $1.1 \times 10^{5}$ & $6.0 \times 10^{8}$ & $5.0 \times 10^{7}$ \\
& $\mathrm{c}$ & $2.1 \times 10^{4}$ & $5.5 \times 10^{4}$ & $5.7 \times 10^{6}$ & $3.5 \times 10^{6}$ \\
& $\mathrm{a}$ & $5.2 \times 10^{3}$ & $4.7 \times 10^{6}$ & $6.5 \times 10^{8}$ & $3.2 \times 10^{8}$ \\
RA & $\mathrm{b}$ & $3.5 \times 10^{4}$ & $4.2 \times 10^{4}$ & $7.0 \times 10^{8}$ & $5.0 \times 10^{7}$ \\
& $\mathrm{c}$ & $3.5 \times 10^{4}$ & $3.7 \times 10^{4}$ & $3.7 \times 10^{7}$ & $3.5 \times 10^{6}$ \\
PDA & $\mathrm{a}$ & $3.7 \times 10^{5}$ & $2.3 \times 10^{4}$ & $8.7 \times 10^{8}$ & $9.7 \times 10^{8}$ \\
& $\mathrm{~b}$ & $5.0 \times 10^{2}$ & $1.7 \times 10^{4}$ & $2.9 \times 10^{8}$ & $1.1 \times 10^{8}$ \\
& $\mathrm{c}$ & $5.0 \times 10^{2}$ & $5.0 \times 10^{3}$ & $3.8 \times 10^{7}$ & $1.4 \times 10^{7}$ \\
AB & $\mathrm{a}$ & $<10^{2}$ & $<10^{2}$ & $6.0 \times 10^{4}$ & $10 \times 10^{4}$ \\
& $\mathrm{~b}$ & $<10^{2}$ & $<10^{2}$ & $<10^{2}$ & $5.0 \times 10^{2}$ \\
& $\mathrm{c}$ & $<10^{2}$ & $<10^{2}$ & $<10^{2}$ & $4.5 \times 10^{3}$ \\
& $\mathrm{a}$ & $<10^{2}$ & $<10^{2}$ & $3.7 \times 10^{8}$ & $1.8 \times 10^{7}$ \\
\hline
\end{tabular}

their major contribution to the ripening process is the utilization of lactic acid, which, by slightly increasing $\mathrm{pH}$ after 28 days of ripening (Table 2 ), encourages growth of bacteria sensitive to acidic environments, and thus helps initiating the second stage of maturation. Pseudomonas were absent from raw and pasteurized milk, but could be detected after 28 days at $10^{8}, 10^{7}$, and $10^{5} \mathrm{cfu} / \mathrm{g}^{-1}$ in the $R, P$ and $P S$ cheeses respectively. On the first day of ripening the counts on M17A were $10^{6}, 10^{4}$, and $10^{4} \mathrm{cfu} / \mathrm{g}^{-1}$ in the $R, P$ and $P S$ cheeses, respectively, and increased to $10^{8}, 10^{8}$, and $10^{7} \mathrm{cfu} / \mathrm{g}^{-1}$ at 28 days. The RA counts were $10^{4}, 10^{4}$, and $10^{3} \mathrm{cfu} / \mathrm{g}^{-1}$ in fresh cheeses and have undergone a considerable increase to $10^{8}, 10^{8}$, and $10^{7} \mathrm{cfu} / \mathrm{g}^{-1}$ by 28 days of ripening in the $R$, $P$ and $P S$ cheeses, respectively. The proteolytic system (proteinases and peptidases) of lactic acid bacteria (lactococci and lactobacilli) is known to play an important role in the development of textural and organoleptic characteristics in mature cheese (Fox, 1989).

\section{Chemical analyses}

Table 2 depicts mean values of two cheese replicates (and associated 99\% confidence intervals averaged in each case over the whole ripening period) of $\mathrm{pH}$ in the centre and at the top of the cheese, moisture content, $\mathrm{NaCl}$ content, fat content, and protein content of the $R$, $P$ and $P S$ cheeses throughout ripening.

The moisture content $(\%(w / w))$ of cheeses was found to decrease almost linearly with time from ca. $61.12 \pm 2.02(62.72 \pm 3.59$ or $60.55 \pm 3.43)$ in fresh cheese to $45.77 \pm 2.02(40.90 \pm 3.59$ or $40.57 \pm 3.43)$ after 68 days in the $R$ ( $P$ or $P S$ ) cheeses, respectively. Most researchers have found that pasteurization of milk resulted in higher final cheese moisture than absence thereof (Moir, 1930; Price \& Call, 1969). However, Price (1927) and Lane \& Hammer (1935) asserted that the moisture content of cheese manufactured from pasteurized milk was similar or slightly lower than that of cheese manufactured from raw milk. The fat content $(\%(w / w T S))$ of fresh cheese was $55.33 \pm 4.94$ $(54.32 \pm 3.41$ or $44.99 \pm 3.56)$ and after 68 days of ripening was $51.17 \pm 4.94(51.63 \pm 3.41$ or $43.75 \pm 3.56)$, while the total protein content $(\%(w / w T S))$ of fresh cheese was $46.33 \pm 1.69(48.31 \pm 2.55$ or $45.66 \pm 2.37)$ and after 68 days of ripening was $33.21 \pm 1.69$ $(30.49 \pm 2.55$ or $30.30 \pm 2.37)$ for the $R(P$ or $P S)$ cheeses, respectively. Although data on fat and protein contents seem erratic throughout the ripening period, it should be emphasized that samples from two independent cheese replicates were assayed in duplicate at each sampling time (i.e. a given cheese was only sampled once throughout the entire experimental program) and the averages of the analytical results for each cheese were in turn averaged to generate a single datum. Cheese manufactured from pasteurized milk retained more fat (Stevenson \& Grant, 1916; Price, 1927) than that manufactured from raw milk, but Lau et al. (1990) have reported that pasteurization of milk had no effect on fat recovery in cheese in spite of increasing nitrogen recovery. The $\mathrm{NaCl}$ content $(\%(w / w T S))$ of the cheeses increased during the first 7 days of ripening, probably due to diffusion of $\mathrm{NaCl}$ from the surface into the inner parts of the cheese. The level of $\mathrm{NaCl}$ throughout the remainder of the ripening period was ca. $4.68 \pm 0.97$ $(4.88 \pm 0.92$ or $3.85 \pm 1.50)$ for the $R(P$ or $P S)$ cheeses, respectively. The variability of $\mathrm{NaCl}$ content was again a result of the sampling protocol utilized, coupled with the fact that cheeses were rubbed independently on their surface with poorly defined amounts of dry crude salt in 


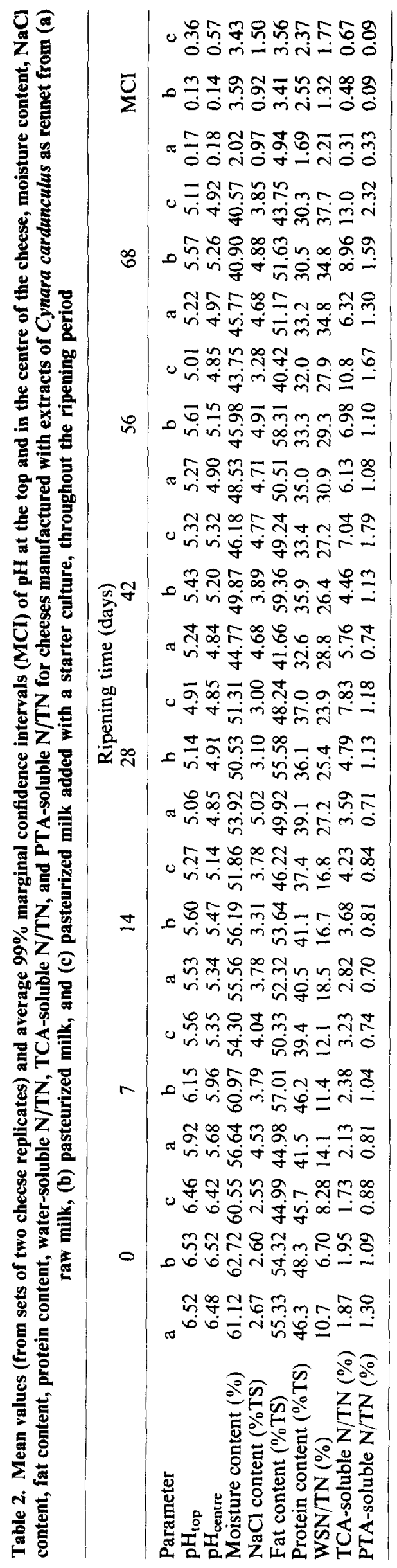



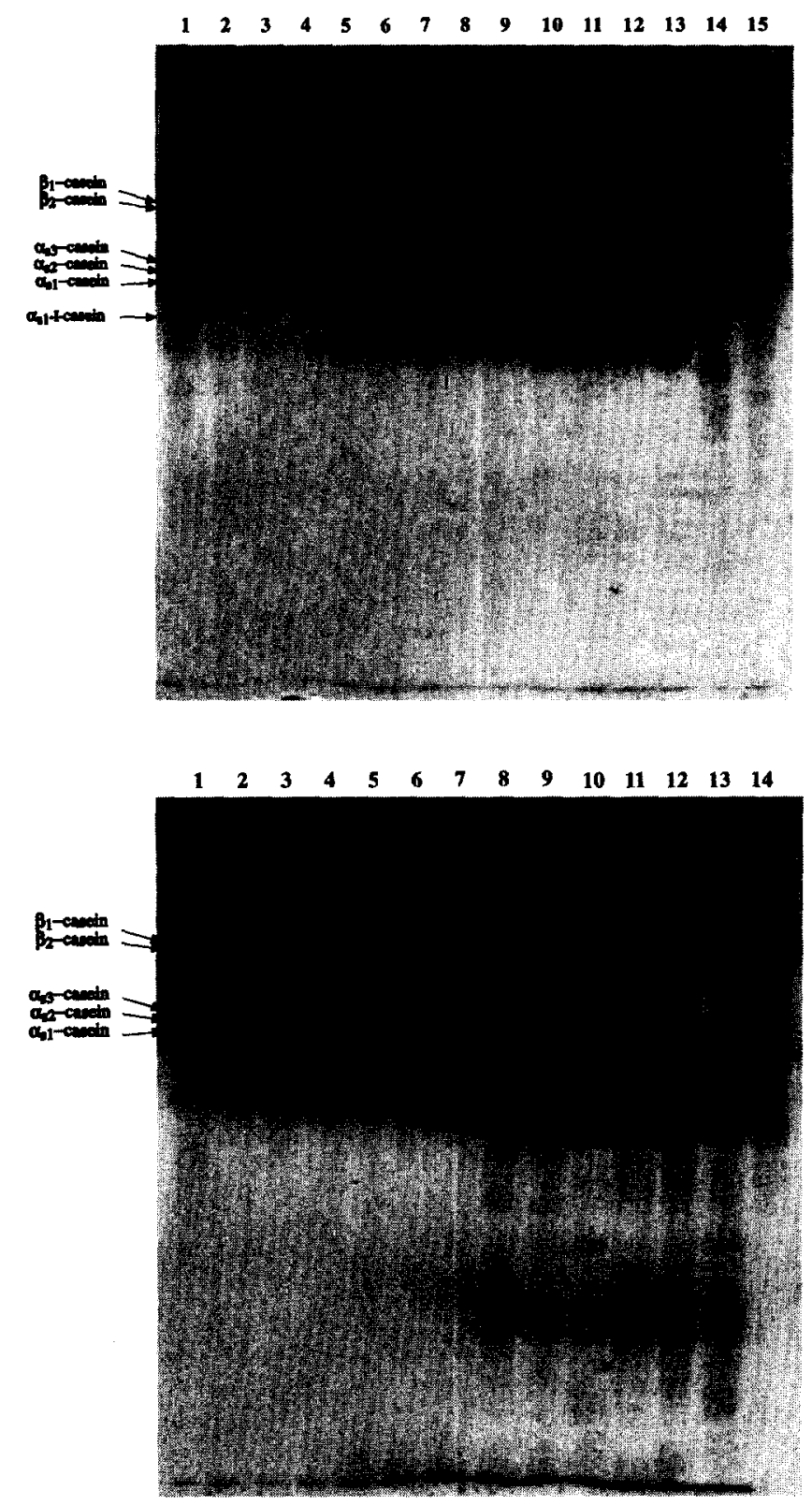

Fig. 1. Urea-PAGE electrophoretograms $(12.5 \% \mathrm{~T}, 4 \% \mathrm{C}$; pH 8.9) of (a: top) the water-insoluble fraction (WISF) and (b: bottom) the water-soluble fraction (WSF), for cheeses manufactured with extracts of $C$. cardunculus and raw milk ( $R$ : lanes $2,5,8$, and 11), pasteurized milk ( $P$ : lanes $3,6,9$, and 12), and pasteurized milk tested with a starter culture (PS: lanes 4,7 , 10 , and 13), after $0,7,28$, and 68 days of ripening. Ovine Na-caseinate (a: lane 1 and 15 ; b: lane 1) and bovine Nacaseinate (a, b: lane 14) were also included as references.

a rather empirical fashion. The salt concentration is of great importance in cheese ripening due to its influence on the proteolytic activity (Fernández del Pozo et al., $1988 b$ ), the specificity of the rennet (Mulvihill \& Fox, 1980 ), and the growth and activity of lactic acid bacteria (Fontecha et al., 1994). High levels of $\mathrm{NaCl}$ can also limit the quantity of available water, thus making cheese harder and less easily deformed (Creamer \& Olson, 1982). Although the average values for protein, fat and salt contents listed in Table 2 do not exactly add up to
$100 \%$, this is a result of the intrinsic variability between cheeses; however, the magnitude of the $99 \%$ marginal confidence intervals in Table 2 indicates that the statistical hypothesis that the sum in question is equal to $100 \%$ is accepted at the $1 \%$ significance level at all ripening times. The $\mathrm{pH}$ at the top and in the centre of the cheeses was found to decrease during the first days of ripening, presumably owing to the production of lactic acid. After 28 days of ripening $\mathrm{pH}$ showed a slight increase, reaching $4.97 \pm 0.18(5.26+0.14$ or $4.92+0.57)$ in the centre of the cheese for the $R(P$ or $P S)$ cheeses, respectively, at 68 days of ripening. A similar trend in $\mathrm{pH}$ was reported for La Serena cheese (Fernández del Pozo et al., 1988b) and for Casar de Cáceres cheese (Poulet et al., 1991) during ripening. This behavior is probably due to metabolism of lactic acid-utilizing yeasts and/or to ammonia production by yeasts acting on the compounds resulting from proteolysis (Noomen, 1978, 1983; Fernández del Pozo et al., $1988 a$ ).

\section{Biochemical analyses}

Table 2 depicts mean values of two cheese replicates (and associated 99\% confidence intervals averaged in each case over the whole ripening period) of WSN/TN, TCA soluble N/TN and PTA soluble N/TN of the $R, P$ and $P S$ cheeses throughout ripening.

Water has been widely used for cheese fractionation (Kuchroo \& Fox, 1982). The ratio WSN/TN (Table 2) increases during ripening, although it is similar for the $R, P$ and $P S$ cheeses at every sampling time. The amount of water-soluble nitrogen was found to increase with ripening time (O'Keefe et al., 1976; Reville \& Fox, 1978) in raw and pasteurized milk cheeses (Lane \& Hammer, 1935; Bullock \& Irvine, 1956). Pasteurization of milk prior to cheesemaking decreased the WSN and FAA found in cheese if compared with cheese manufactured from raw milk (Kosikowski, 1951; Bullock \& Irvine, 1956; O'Keefe et al., 1976). McSweeney et al. (1993b) reported no differences in WSN levels in raw and pasteurized milk cheeses, although amino acid nitrogen was consistently higher in raw cheeses than in pasteurized milk cheeses. The high initial WSN/TN observed can be attributed to the high initial cheese moisture content and the type of plant rennet used. Soluble nitrogen components are produced mainly via action of rennet (O'Keefe et al., 1976; Desmazeaud \& Gripon, 1977; Visser, 1977). However, starter and, to a lesser extent, milk proteinase also play a role in producing soluble- $\mathrm{N}$ compounds in cheese independently of the action of rennet (Visser, 1977).

The ratios TCA-soluble/TN and PTA-soluble/TN, which have been widely used as indicators of maturation of cheese (Venema et al., 1987), were similar for the $R$ and $P$ cheeses (Table 2). Lau et al. (1991) found that the amount of $12 \%$ TCA-soluble nitrogen in cheese manufactured from pasteurized milk was lower than 
that manufactured from raw milk. Similar observations were made by Lane \& Hammer (1935) when measuring amino acid nitrogen, 1\% PTA-soluble nitrogen, and 2\% TCA-soluble nitrogen. However, the TCA-soluble/TN ratio and the $\mathrm{PTA}$-soluble/TN ratio for $P S$ cheeses ripened for more than 28 days were higher than those for $R$ and $P$ cheeses ripened for the same time, this is in agreement with O'Keefe et al. (1978), who concluded that the action of starter enzymes leads primarily to the formation of small peptides and amino acids (which account for $\mathrm{N}$-soluble in $12 \%$ TCA). The $12 \%$ TCAsoluble fraction contains small peptides (2-20 residues) (Yvon et al., 1989) and amino acids, while the large and medium peptides are found in the precipitate (Reville \& Fox, 1978; Kuchroo \& Fox, 1982). Fractionation with $5 \%$ PTA only extracts low molecular weight peptides ( $<600 \mathrm{Da}$ ). Rennet (a crude mixture of chymosin and pepsin) releases peptides of high and low molecular weight, but only very low amounts of amino acids. Kuchroo \& Fox (1982) demonstrated that $58 \%$ of the water-soluble $\mathrm{N}$ remained soluble in 5\% PTA. The low values for the PTA-soluble N/TN ratios of raw milk cheeses suggest that casein was cleaved by proteinases of the flowers of $C$. cardunculus into high-molecular weight peptides, and thus indicates that the plant rennet preparation has a low peptidase activity (Heimgartner et al., 1990; Nuñez et al., 1991). In La Serena cheeses (manufactured with extracts of $C$. cardunculus as coagulant) the level of both 5\% PTA- and $12 \%$ TCA-soluble $N$ fractions showed significant correlations to residual $\alpha_{\mathrm{sl}}$-casein throughout maturation, but this correlation was not found for residual $\beta$ casein.

The water-insoluble nitrogen (WISN) fraction contains caseins and high molecular weight products of casein breakdown and such extract was to advantage analysed by urea-PAGE (Desmazeaud \& Gripon, 1977). The urea-PAGE electrophoretograms of the WISN fraction from cheese (Fig. 1a) were similar for the $R, P$ and $P S$ cheeses at 68 days of ripening. The urea-PAGE electrophoretograms of the WSN fraction of the $R$ and $P$ cheeses (Fig. 1b) at 28 days of ripening exhibit two bands instead of the three bands exhibited by the $P S$ cheese at the same mobility. Another difference was also apparent between the WSN fraction of the $R$ and $P$ cheeses after 68 days of ripening, which showed 2-3 small bands with lower mobility than the main band, and the $P S$ cheese, which did not show any such bands. McSweeney et al. (1993a) reported that raw and pasteurized milk cheeses and their watersoluble extracts were indistinguishable by urea-PAGE for up to 3 months, but slight differences became apparent by 6 months. The major difference between the cheeses was therefore in respect to small peptides and free amino acids, indicating a higher extent of proteolysis in the raw milk cheese, presumably due to proteinases and peptidases from NSLAB (McSweeney et al., 1993b).

\section{ACKNOWLEDGEMENTS}

Financial support for M. J. S. was provided by a Ph.D. fellowship issued by program PRAXIS XXI (BD-2763/93). Partial funding for this research work was provided through grants within program AAIR (project Design and production of an enzymatic and microbial mixture to improve the process ewe's cheese (Spain, France, Italy and Portugal) safety and quality and to get a novel functional food as a response to European demand for new products low in cholesterol and protein enriched) and by Agência de Inovação (project MAQUETTE: MelhorAmento de QUEijos Tradicionais e sua TEcnologia). The authors are deeply indebted to the members of Estação Experimental de Lacticinios (Paços de Ferreira) for their cooperation in the experimental manufacture and ripening of cheeses under the auspices of Direcção Regional de Agricultura de Entre Douro e Minho (D.R.A.E.D.M., Portugal).

\section{REFERENCES}

Andrews, A. T. J. (1983). Proteinases in normal bovine milk and their action on caseins. J. Dairy Res., 50, 45-55.

Anon. (1975). ISO 3433: Method Van Gulik.

Aston, J. W., Durward, I. G. \& Dulley, J. R. (1983). Proteolysis and flavour development in Cheddar cheese. Aust. J. Dairy Technol., 38, 55-59.

Blakesley, R. W. \& Boezi, J. A. (1977). A new staining technique for proteins in polyacrylamide gels using Coomassie Brillant Blue G-250. Anal. Biochem., 82, 55-581.

Bullock, D. H. \& Irvine, O. R. (1956). A chromatography study of Cheddar cheese ripening. .I. Dairy Sri., 39, 12291235

Busta, F. F., Peterson, E. H., Adams, D. M., Johnson, M. G. (1984). Colony count methods. In Compendium of Methods for the Microbiological Examination of Foods, ed. M. L. Speck. American Public Health Association, Washington DC, pp 62-82.

Creamer, L. K. \& Olson, N. F. (1982). Rheological examination of maturing Cheddar cheese.. J. Food Sci, 47, $631-636$

Desmazeaud, M. J. \& Gripon, J. C. (1977). General mechanism of protein breakdown during cheese ripening. Milchwiss., 32, 731-734.

Fernández del Pozo, B., Gaya, P., Medina, M., RodriguezMarín, A. \& Nuñez, M. (1988a). Changes in the microflora of La Serena ewe's milk during ripening. J. Dairy Res., 55, 449-455.

Fernández del Pozo, B., Gaya, P., Medina, M., RodriguezMarín, A. \& Nuñez, M. (1988b). Changes in chemical and rheological characteristics of La Serena ewe's milk during ripening. J. Dairy Res., 55, 457-464.

Fontecha, J., Peláez, C., Juarez, M., Requena, M. T., Gómez, C. \& Ramos, M. (1990). Biochemical and microbiological characteristics of artisanal hard cheese varieties. J. Dairy Sci., 73, 1150-1157.

Fontecha, J., Peláez, C. \& Juarez, M. (1994). Biochemical characteristics of a semi-hard ewe's milk cheese. $Z$. Lebensm. Unters. Forsch., 198, 24-28.

Fox, P. F. (1989). Proteolysis during cheese manufacture and ripening. J. Dairy Sci., 72, 1379-1400.

Fryer, T. F. \& Sharpe, M. E. (1966). Pediococci in Cheddar cheese. J. Dairy Res., 33, 325-331. 
Furtado, M. M. \& Partridge, J. A. (1988). Characterization of nitrogen fractions during ripening of soft cheese made from ultrafiltration retentates. J. Dairy Sci., 71, 2877-2885.

Heimgartner, U., Pietrzak, M., Geertsen, R., Brodelius, P., da Silva Figueiredo, A. C. \& Pais, M. S. S. (1990). Purification and partial characterization of milk clotting proteases from flowers of Cynara cardunculus. Phytochem., 29, 1405-1410.

Kosikowski, F. V. (1951). The liberation of free amino acids in raw and pasteurized milk Cheddar cheese during ripening. J. Dairy Sci., 34, 235-242.

Kosikowski, F. V. (1982). Analysis. In Cheese and Fermented Milk Foods. F. V. Kosikowski and Associates, Brooktondale, New York.

Kuchroo, C. N. \& Fox, P. F. (1982). Soluble nitrogen in Cheddar cheese: comparison of extraction procedures. Milchwiss., 37, 331-335.

Lane, C. B., Hammer, B. W. (1935). Bacteriology of cheeses. I. Effect of pasteurizing the milk on the nitrogenous decomposition in Cheddar cheese. Res. Bull., 183. Iowa Agric. Exp. Stn., Ames.

Lau, K. Y., Barbano, D. M. \& Rasmussen, R. R. (1990). Influence of pasteurization on fat and nitrogen recoveries and Cheddar cheese yield. J. Dairy Sci., 73, 561-570.

Lau, K. Y., Barbano, D. M. \& Rasmussen, R. R. (1991). Influence of pasteurization of milk on protein breakdown in Cheddar cheese during ripening. J. Dairy Sci., 74, 727-740.

Law, B. A., Castañon, M. \& Sharpe, M. E. (1976). The effect of non-starter bacteria on the chemical composition and the flavour of Cheddar checse. J. Dairy Res., 43, 117-125.

Marth, E. H. (1963). Microbiological and chemical aspects of Cheddar cheese ripening. A review. J. Dairy Sci., 46, 869-890.

Martley, F. G. \& Crow, V. L. (1993). Interactions between non-starter microorganisms during cheese manufacture and ripening. Int. Dairy J., 3, 461-483.

McSweeney, P. L. H., Fox, P. F., Lucey, J. A., Jordan, K. N. \& Cogan, T. M. (1993a). Contribution of indigenous microflora to the maturation of Cheddar cheese. Int. Dairy $J ., 3,613-634$

McSweeney, P. L. H., Pochet, S., Fox, P. F. \& Healy, A. (1993b). Partial identification of peptides from the waterinsoluble fraction of Cheddar cheese. J. Dairy Res., 61, 587590

Melachouris, N. P. \& Tuckey, S. L. (1966). Changes of proteins in Cheddar cheese made from milk heated at different temperatures. J. Dairy Sci., 49, 800-808.

Miles, A. A. \& Misra, S. S. (1938). The estimation of the bactericidal power of the food blood. J. Hyg., 38, 732-749.

Moir, G. M. (1930). Pasteurized milk for Cheddar cheesemaking. I. A preliminary chemical investigation. $J$. Dairy Res., 1, 149-155.

Mulvihill, D. M. \& Fox, P. F. (1980). Proteolysis of $\alpha_{\mathrm{s} 1}$-casein by chymosin in dilute $\mathrm{NaCl}$ solutions and in Cheddar cheese. Ir. J. Food Sci. Technol., 4, 13-23.

Naylor, J. \& Sharpe, M. E. (1958). Lactobacilli in Cheddar cheese 3. The source of lactobacilli in cheese. J. Dairy Res., 25, $431-438$

Noomen, A. (1978). Activity of proteolytic enzymes in simulated soft cheeses (Meshanger type). 2. Activity of calf rennet. Neth. Milk Dairy J., 32, 49-68.

Noomen, A. (1983). The role of the surface flora in the softening of cheeses with a low initial pH. Neth. Milk Dairy J., 37, 229-232.

Nuñez, M., Fernández del Pozo, B., Rodriguez-Marin, M. A. Gaya, P. \& Medina, M. (1991). Effect of vegetable and animal rennet on chemical, microbiological, rheological and sensory characteristics of La Serena cheese. J. Dairy Res., $58,511-519$.

O'Keefe, R. B., Fox, P. F. \& Daly, C. (1976). Contribution of rennet and starter proteases to proteolysis in Cheddar cheese. J. Dairy Res., 43, 97-107.

O'Keefe, A. M., Fox, P. F. \& Daly, C. (1978). Proteolysis in Cheddar cheese: role of coagulant and starter bacteria. $J$. Dairy Res., 45, 465-477.

Perry, K. D. \& McGillivray, W. A. (1964). The manufacture of 'normal' and 'starter free' Cheddar cheese under controlled bacteriological conditions. J. Dairy Res., 31, 155165

Poulet, B., Huertas, M., Sánchez, A., Cáceres, P. \& Larriba, G. (1991). Microbial study of Casar de Cáceres cheese throughout ripening. J. Dairy Res., 58, 231-238.

Price, W. V. (1927). Cheddar cheese from pasteurized milk. $J$. Dairy Sci., 10, 155-162.

Price, W. V. \& Call, A. O. (1969). Cheddar cheese: comparison of effects of raw and heated milk on quality and ripening. $J$. Milk Food Technol., 32, 304-310.

Reiter, B., Fryer, T. F., Pickering, A., Chapman, H. R., Lawrence, R. C. \& Sharpe, M. E. (1969). The effect of the microbial flora on the flavour and free fatty acid composition of Cheddar cheese. J. Dairy Res., 34, 257-272.

Reville, W. J. \& Fox, P. F. (1978). Soluble protein in cheddar cheese: comparison of analytical methods. Ir. J. Food Sci. Technol., 2, 67-76.

Scarpclino, R. \& Kosikowski, F. V. (1962). Evolution of volatile compounds in ripening raw and pasteurized milk Cheddar cheese observed by gas chromatography. J. Dairy Sci., 45, 343-351.

Shalabi, S. I. \& Fox, P. F. (1987). Electrophoretic analysis of cheese: comparison of methods. Ir. J. Food Sci. Technol., 11, 135-151.

Sherwood, I. R. (1936). Observations on the ripening of cheeses made from raw and pasteurized milk. J. Dairy Res., 7, 271-279.

Stevenson, C. \& Grant, W. (1916). Pasteurization of milk for cheesemaking. N. Z. J. Agric., 12, 440-445.

Thomas, S. B., Egdell, J. W., Clegg, L. F. L. \& Cuthbert, W. A. (1950). Thermoduric organisms in milk. Part I. A review of the literature. Proc. Soc. Appl. Bacteriol., 13, 27 64.

Turner, K. W. (1988). Some aspects of the microbiology of cheese ripening investigated using aseptic manufacturing techniques. Ph.D thesis, Massey University, Palmerston North, N. Z.

Venema, D. P., Herstel, H. \& Elenbaas, H. L. (1987). Determination of the ripening time of Edman and Gouda cheese by chemical analysis. Neth. Milk Dairy J, 41, 215-226.

Visser, F. M. W. (1977). Contribution of enzymes from rennet, starter bacteria and milk to proteolysis and flavour development in Gouda cheese. 3. Protein breakdown: analysis of the soluble nitrogen and amino acid nitrogen fraction. Neth. Milk Dairy J., 31, 210-239.

Visser, F. M. W. \& de Groot-Mostert, A. E. A. (1977). Contribution of enzymes from rennet, starter bacteria and milk to proteolysis and flavour development in Gouda cheese. 4 Protein breakdown: a gel electrophoretic study. Neth. Milk Dairy J., 31, 247-264.

Yvon, M., Chabanet, C. \& Pélissier, J. P. (1989). Solubility of peptides in trichloroacetic acid (TCA) solutions. Int. J. Peptide Protein Res., 34, 166-176. 